[Woodhams, M. (2008). Looking a Gift Horse in the Mouth: Examining Labour's "20 Hours Free" Early Childhood Education Policy, New Zealand Annual Review of Education, 17, 169-185]

\section{Looking a Gift Horse in the Mouth: Examining Labour's "20 Hours Free" Early Childhood Education Policy}

\section{MAUREEN WOODHAMS}

\section{Abstract:}

In 2007 the Labour-led coalition government introduced a provision of 20 hours free early childhood education in teacher-led services for all three-and four-year old children. This policy was linked to the goal of increasing participation in the government's strategic plan for early childhood education, by removing cost as a barrier to children's participation in approved services. This article begins by outlining the context in which this policy was developed. As a Third Way administration, the Labour-led coalition government has particular beliefs and goals for the country, but also operates in an environment where compromises on policy are necessary. The language of the policy is then examined to highlight the discourses which it privileges. Where certain practices or behaviours are promoted by those in power as normal or "common sense" they obscure alternative choices and are a means of managing public behaviour. While the policy development process involves multiple contributors, the government, by its position, has a unique ability to affect which discourses are privileged. Finally, the policy itself is critically examined from a theoretical perspective. The article concludes by suggesting that the policy, while positioned by the Minister as an education policy, is as much about conditioning parents to place their young children in out-of-home care so that they themselves can participate in the workforce.

n its May 2004 budget, the Labour-led coalition government announced its intention to fully fund 20 hours per week of early childhood education (ECE) for all three- and four-year old children enrolled in teacher-led, community-based services, from 1 July 2007 . In August 2005 it was announced that the policy would be extended to include private, for-profit services. It was described as "the most significant expansion of the education system since the rollout of free secondary education by the first Labour government in the 1930s" (Maharey, 2007a), and it reflects the importance the coalition government places on ECE for children's development. In its strategic plan for early childhood education, Pathways to the Future: Ngā Huarahi Arataki (Ministry of Education, 2002), the government described ECE as "a critical first step in building the foundation for a child's ongoing learning and development" (p. 3). By maximising each individual's educational potential, the government hoped to both increase New Zealand's performance internationally and include every citizen in future economic growth.

While the policy was greeted with warm acclaim by many in the sector, it has not received much critical attention. What comment there has been has focused largely on issues such as the funding rates - for some these are not high enough - and the uneven availability of child places around the country. In addition, a few commentators have drawn attention to problems inherent in the design of the policy and the effect it may have on parent-led services and on children's lives (Farquhar, 2007)

\section{The "Third Way"}

The Labour-led coalition government, elected in New Zealand in 1999 has been characterised as a "Third Way" government. Third Way adherents see themselves as using market based mechanisms (a feature of neoliberalism) to achieve socially inclusionary goals (traditionally the sphere of social democrats). They speak of "social investment" and "developing social capital". They hope to create a more inclusive and egalitarian society by: increasing employment; improving access to "high-quality" education and health services; and strengthening the "third sector" - community, voluntary and (in New Zealand) tangata whenua organisations. In achieving these aims, however, they make use of "neoliberal" mechanisms such as contestable funding and rigorous accountability requirements. Giddens (1998) states that "it is a third way in the sense that it is an attempt to transcend both old style social democracy and neoliberalism" (p. 26). For example, in New Zealand the Labour-led coalition government replaced the highly individualistic Employment Contracts Act 1991 with the Employment Relations Act 2000. This latter Act explicitly encouraged unions and employers in "good faith negotiation" while retaining voluntary unionism and market-based elements from the previous Act. 
A key tenet of the Third Way approach is that employment is "the only secure and sustainable means to social inclusion" (Whyman, 2006, p. 19), and that government can best help its citizens by providing education and training to enable individuals to compete successfully in the marketplace. Accordingly, on gaining power, the Labour-led coalition government emphasised education policies. It acted quickly to reverse certain policies of the previous National government, for example, by reinstating a system of school zones and by redesigning school financing to improve funding for schools serving lower socio-economic communities (Thrupp, 2001, p. 190). Both of these policies were intended to improve educational and thus employment opportunities for people in lower socio-economic status communities.

Under Third Way theory, citizens are offered equality of opportunity through investment in education, but are responsible for maximising their opportunities. Social inclusion is seen as occurring through participation in the workforce, and markets are seen as an acceptable and efficient way to deliver some social goals, for example, those that enable workforce participation. The Labour-led government was also anxious to appear friendly to business, initiating forums in its first term to gauge the needs of business, and appeared sensitive to criticism from business. Third Way governments allow community groups to make their own decisions about community development and operations, but then hedge them with accountability requirements, requiring them to meet the government's own goals. This has created tensions in a number of policy areas, including education.

Early Childhood Education (ECE) is a key policy area in which the Third Way has advanced its agenda. As the prominence of ECE grew in society over the past two decades, Third Way governments started to realise the ways in which ECE could achieve some of their policy aims. The Third Way approach emphasises both employment and equality of opportunity for all members of society. Research, including the Competent Children, Competent Learners study (Wylie et al., 1996), showed that good quality ECE prepares children to succeed at school, especially children from disadvantaged backgrounds, thereby lifting their future participation and performance in the workforce. ECE can also have the immediate effect of aiding women's participation in the workforce, increasing family income and helping mothers to "participate" in society.

Ball and Vincent (2005) describe how New Labour, a Third Way government in England, believed that ECE could address a number of policy areas, including "combating child poverty, revitalising the labour market, and raising standards in education" (p. 558). The New Zealand Labour-led coalition government has expressed similar ideas. For example, the then Minister of Education identified ECE as the foundation for success for both children and for New Zealand, and of most benefit to children from low socio-economic backgrounds (Ministry of Education, 2002, p. 1). Expressing concern for New Zealand's competitiveness under increasing globalisation, a later Minister also stated that "We are transforming New Zealand to a knowledge-based economy and society; ... a country competing on the global stage.... Quality early childhood education ... enables our children to contribute strongly to the knowledge society" (Maharey, 2007b). With near full employment, the government was also interested in encouraging more mothers into the workforce in order to lift productivity (Clark, 2005). It seemed that ECE, if of appropriate quality and in the right locations, could be an important step in achieving the Labour-led coalition's goals.

\section{Developments in Early Childhood Education}

Early childhood education has achieved increasing prominence in New Zealand over the past 20 years. There has been a dramatic increase in the number of early childhood (EC) services and in enrolments of children in those services, particularly in the education and care sector (Robertson, 2007, p. 6). This reflects the increase in workforce participation of mothers with young children, growing acknowledgment of the benefits to children of some out-of-home ECE, and increased government funding for services. Extensive lobbying by the early childhood community led to significant changes in the EC sector in the 1980s. Notable achievements included the alignment of care and education under the new Ministry of Education, the introduction of the three-year teaching diploma as the benchmark qualification for both childcare and kindergarten teaching, and a new, increased, funding system introduced by the Labour government (May, 2001, pp. 206-7, 214).

A change of government in 1990, however, meant that the implementation of the staged funding scheme was halted at the first step. The National government reviewed funding at an ideological level, viewing ECE as a social service, with the community encouraged "to move from state dependence to personal and self reliance" (May, 2001, p. 219), and cutting absolute funding levels for some groups. Nevertheless, other initiatives of the 1990s advanced the status of the 
sector. The early childhood curriculum framework, Te Whāriki: He Whāriki Mātauranga mō ngā Mokopuna o Aotearoa (Ministry of Education, 1996), was a highly successful and internationally recognised development which resulted from wide collaboration between EC sector groups, ably led by Margaret Carr, Helen May, Tilly Reedy and Tamati Reedy. Also, an important longitudinal study, the Competent Children, Competent Learners study (Wylie et al., 1996) was initiated, as an evaluation of the impact of children's early childhood experiences on later learning development. This proved to be a key piece of research in understanding the long-term benefits of ECE in the unique New Zealand context.

Another early childhood sector initiative during the 1990s which was to have lasting impact was the Future Directions document (Early Childhood Education Project, 1996). Frustrated by several years of "top-down" and non-consultative review of the sector by National governments, a working party was initiated in 1995 by NZEI (including sector representatives), in order to restate goals for education and care, and to articulate steps which should be taken to provide quality ECE for all children, as of right. The three goals identified in the document were: universal funding for ECE on an equitable basis with schools; partnership between government, the sector and parents in policy development; and a strategic plan for early childhood (Mitchell, 2005). This document, released in 1996, influenced opposition education manifestos, and the incoming Labour government in 1999 incorporated some of its goals (May, 2001, p. 221).

A theme which developed through the 1990s was the discourse of quality in ECE. The managerial approach to education favoured by previous New Right administrations required that, where public money was to be spent, there must be some measure of accountability and auditing. Regulated standards for ECE were defined in 1990, and higher, "quality" standards in 1996, which would attract a small increase in funding, with the Education Review Office acting as auditor to ensure compliance. At the time many academic studies, particularly from North America, linked certain structural and process factors, such as staff qualifications, group size, adult:child ratios and responsive adult/child relationships, to the quality of experience for children in group care (e.g., Podmore \& Meade, 2000; Shepherd \& Eaton, 1997; Smith, 1996). A shift in theoretical framework within ECE began to occur during the 1990s from developmentally appropriate practice (DAP) to a socio-cultural perspective on learning (Smith, 1996, p. 331). This led to the notion of quality being questioned: what it might mean, and how it was experienced by children and families (Farquhar, 1999). Different families have different values, and communities have different requirements; a "one size fits all" approach to the provision of quality children's services will not provide the same outcomes for all. Nevertheless, after the 1999 election, the new Labour-led coalition government continued to emphasise structural factors in defining quality education. Indeed, while acknowledging that a range of factors contribute to quality, it focused largely on teacher qualifications, perhaps having noted the movement within the EC sector for professional status equivalent to the compulsory school sector. A focus on qualifications as the most important determiner of quality in ECE is both easy to administer, and means that changes to achieve quality become the responsibility of those who wish to work in the sector.

After election in 1999, and influenced by the Future Directions report, the Labour-led coalition started to develop, with intensive consultation across the EC sector, Pathways to the Future: $N g \bar{a}$ Huarahi Arataki (Ministry of Education, 2002), the ten-year strategic plan for early childhood (Dalli $\&$ Te One, 2002, p. 181). When this was released in 2002, the three broad goals of the strategic plan were to "increase participation in quality ECE; improve quality of ECE; and promote collaborative relationships" (Ministry of Education, 2002, p. 2). The strategic plan laid out a comprehensive network of interconnecting strategies to achieve its goals, but also acknowledged that some strategies would be further developed as the plan unfolded (p. 3). A key plank in the Labour-led coalition's efforts to increase participation in ECE was to provide 20 hours per week free education for older pre-schoolers. This policy is discussed in more detail in what follows.

\section{Free Hours Policy}

In its budget of May 2004, the government announced its intention to provide all three- and four-year old children with 20 hours per week of free education from 1 July 2007. Described as an entitlement, and available in community-based, teacher-led services, this policy advanced the strategic plan goal of increasing participation, by aiming to remove cost as a barrier to children's participation in ECE and so increase the hours of attendance of individual children. The goal required children to attend quality ECE services, and the policy defined these as services run by not-for-profit organisations and staffed by qualified teachers.

In August 2005, during the election campaign, the Free ECE policy was extended to include private ECE services, following extensive 
lobbying by the Early Childhood Council (ECC), a sector group representing mainly private childcare centres. The rationale was that this would ensure more children would be able to access the free entitlement. The claim that ownership of a service does not affect the quality of education was stressed by ECC and opposition politicians. The policy continued to exclude services led by trained parent volunteers.

\section{Discourse Analysis of the Text}

When developing policy, a government chooses language which highlights ideas, values and activities which are important to it, and which it wishes to encourage. In examining the text of a policy statement it becomes important to consider which discourses are privileged in order to understand what alternative views and values may be obscured by the policy and its language. The term discourse refers to the categories we use to make sense of, and engage with, our social world. Dahlbeg et al. (2007) note that"the importance of discourse comes from the decisive role of language in constructing the world, rather than being simply a means of representing or copying reality (p. 31). There may be many discourses on a single topic. For example, the child may be viewed as an "independent child", who benefits from early separation from home figures and engagement with diverse others, or as a "secure explorer", who uses the parent as a secure base from which to explore the world at its own pace (Cannella, 1997, p. 42). Different discourses are accounted varying degrees of weight or power depending on the social and political climate; some discourses are taken as more truthful, as "common sense" (Weedon, 1997, p. 34).

The Free ECE policy provides that all three- and four-year old children are eligible to receive up to 20 hours per week ECE at teacher-led services from 1 July 2007, at no cost to their parents. The Minister of Education is adamant that this is an education, not workforce, policy. At the New Zealand Childcare Association (NZCA) conference he stated, "This is not a labour market policy, it's an education policy. It's based on the conviction, and the evidence, that if we invest in starting to educate young people from the age of three, we get a real result for kids right throughout the education system and hopefully throughout their lives as a result" (Maharey, 2007a). That being the case, the policy is structured to identify education with separating children from their parents, for increased hours per week, in groups supervised by paid professionals, and where money is the key determiner to access. By implication it neglects the fact that education may occur in non-institutional settings and with parents, and that other values may be more important to some parties.

The universal nature of the policy tallies with the Third Way focus on equality of opportunity for all children to education, and therefore to employment opportunities. However, the policy is structured so that only parents who enrol their children in certain services benefit from it, and this, combined with other government rhetoric, suggests an expectation of a parental involvement in training or employment rather than hands-on parenting. In the following, the language used by the government around the Free ECE policy is examined for privileged and hidden discourses and values.

\section{"Education occurs in institutions only"}

In this policy, the government defines education as occurring in institutional settings only. The Strategic Plan for early childhood education, Pathways to the Future: Ngā Huarahi Arataki (Ministry of Education, 2002) contains some reference to the learning which children do in their home setting and from the earliest age. At one place it acknowledges that "parents are key in their children's development and most children experience much of their early learning within the home" (Ministry of Education, 2002, p. 5). Reference elsewhere in the plan, however, is to early childhood education as something which children must access, and which is a sector made up of licensed and license-exempt services (p. 1). The three goals of the plan, to "increase participation in quality ECE services; improve quality of ECE services; [and] promote collaborative relationships" (p. 2, italics added) are all framed as occurring between children/parents and services. There are no goals to support the learning which occurs in the home.

With the introduction of the Free ECE policy, however, this discourse is taken to a new extreme. The government appears to believe that no education occurs before a child starts at an institution. A widely circulated pamphlet states that "one of the best things you can do for your child is to start their education early", and "from 1 July 2007, it will be easier than ever to start your child's learning early because up to 20 hours of ... ECE will be free for three and four year olds" (Ministry of Education, n.d.) The implication is plain: whatever happens before the child starts at an (eligible) service, it is neither learning nor education.

"Quality = teachers"

In the Free ECE policy the government defines quality education as only that which is delivered by teachers. The strategic plan acknowledges 
services run by parents and whanau, with a goal stating that "the particular support needed by parents and whanau supplying ECE services will be further investigated" (Ministry of Education, 2002, p. 3). The implementation of the plan, however, has focussed mainly on teachers. The Minister of Education has said that "a particular focus through the strategic plan has been ensuring that quality ECE provision is directly linked to quality teachers" ( Maharey, 2007b). This emphasis has been reflected by academics promoting a professionalised early childhood teaching service (Dalli, 2006). With the plan currently at the half-way point, it is notable that priority has been given to implementing aspects which relate to the professionalisation of EC teaching, and to increasing the proportion of trained teachers in services (Dalli \& Te One, 2002, p. 181). There have been no substantive initiatives primarily directed at supporting parent-led services.

The Free ECE policy is a flagship policy, and the publicity and promotion material consistently uses the phrases "quality ECE" and "teacher-led services" (Ministry of Education, n.d.). The implication is that services which are not offering Free ECE and which do not have qualified teachers are not quality services. However, independent research demonstrates that qualifications are only one of several variables which produce quality outcomes for children, and that services with a high level of parental involvement, such as Playcentre, provide a high quality education without employing teachers (Wylie et al., 1996; Education Review Office, 2000; van Wijk et al., 2006).

\section{"More hours of ECE is better"}

The government is stating that children should attend more hours of ECE. The amount of 20 hours per week has been chosen "to encourage regular and intensive participation in quality ECE" as the government claims that "children don't benefit from quality ECE if their participation is not intensive enough" (Maharey, 2007c). Currently, three- and fouryear olds attend ECE services for an average of 14-17 hours per week, and the government has positioned this as "relatively few". To support this claim the government uses findings from the Competent Children, Competent Learners study (Wylie et al., 1996). However, in an analysis of the study and the way its findings are used by government, Farquhar and Croad (2005) dispute both the claim itself, and that the study demonstrates it. Hours attended per week were not a variable used in the research, and the research gives no information about optimal hours of ECE attendance (p. 11). The playcentres in the survey produced outcomes that were at least equal to those in other services, despite the fact that maximum attendance for playcentre sessions at that time was ten hours per week (Wellington Playcentre Association, 1992). Furthermore, a survey of international ECE research found no evidence that full-time attendance produced better outcomes for children, compared to part-time (Mitchell et al., 2008, p. 35)

Participation in an EC service exposes the individual child to new experiences, and the child's parent to new ideas and role models for parenting interactions. For a small minority of children, the alternative to attending group ECE is such an impoverished experience that increased hours must be an advantage (Smith et al., 2000, p. 4). However, there is a tension between the focus on workforce participation and parent/child outcomes which the policy does not appear to recognise. There is likely to be a point at which further time in ECE services ceases to produce benefits for the child and comes at the expense of encouraging active parenting.

\section{"Cost is the only barrier"}

The government positions cost as the only barrier to participation in ECE. The aim of the policy is "to encourage regular and intensive participation in quality ECE, which is proven to have a positive effect on their education" (Maharey, 2007c). The method chosen to achieve this aim is to fund the average cost of ECE at teacher-led services for threeand four-year old children, so that parents will not need to pay fees for the first 20 hours per week. By identifying cost as the most important barrier to quality ECE for families the government has positioned parents as consumers, education as a product to be purchased, and money as the relevant value. Other values, such as personal fulfilment, the opportunity to participate in the community and the education method which suits the child, are hidden and deemed irrelevant. Interestingly, Playcentre is specifically excluded from the policy because "for families using parent-led services such as Playcentres, family members contribute their valuable time by educating children at the service. This means there is usually a lower cost barrier, so 20 Hours Free ECE would not necessarily increase participation in parent-led services" (Maharey, 2007c). Parental time and administrative burdens may be a barrier to participation in parent-led services, but this is constructed as being irrelevant.

Other potential barriers to participation are known to exist, including transport issues, health issues and lack of confidence in EC 
services (Dixon et al., 2007, p. 8), but these are also not considered. In particular, it is unclear whether cost is the main barrier for those families whose children are currently not attending any ECE service (p. 44). In failing to consider other barriers to participation the policy further marginalises those whose priorities are outside the established norm, while also threatening established services whose "costs" are measured in more than dollars.

\section{Discussion}

The Free ECE policy is indeed a radical development in early childhood education. It recognises the importance of early learning and takes the government's responsibility to support such learning to a new level. As with all radical policy provisions it has both positive and negative elements. How these are identified depends on one's point of view and the relative weighting one gives to elements which may be in tension. In their structure of, and talk about, the Free ECE policy, the government has made choices about what they believe will most benefit the country. The Third Way emphasises equality of access to education as a means to successful employment, and that full participation in the workforce is the basis of community participation. This section will highlight how the policy supports some aspects of these intentions, but how it also creates some contradictions.

The policy continues to be one of universal access regardless of parents' income or social status. This supports all children benefiting from a similar form of educational opportunity. By making a significant investment in $\mathrm{ECE}$, the government is demonstrating that they value the learning of young children, and want parents to also value it. Additionally, for the families for whom the cost of their chosen service is a hurdle, the policy is likely to offer some relief. In turn, the policy may make it easier to operate EC services in some areas, as the funding stream is more predictable than parent fees.

However, there are contradictions between the policy's design and the government's purported interest in community self determination and independence. New Zealand boasts a rich variety of well-regarded ECE services, including those, such as Playcentre and Kohanga Reo, which were developed for the unique local circumstances, produce excellent outcomes for children and communities and involve high levels of parental participation (Education Review Office, 2000). A section of the community chooses to educate its children through these services. Yet the policy is not extended to services which value parent participation over teacher qualifications. The preferred choice of these parents is overlooked. One could reasonably expect an educational policy to fund services based on educational outcomes. If a service provides quality outcomes for children, is preferred by some communities of parents, and would not be prohibitively expensive, then the only reasonable conclusion to draw is that the policy is manipulating parents' choices to meet other goals of the government.

Another contradiction in the policy design is that Playcentre is excluded on account of a traditional practice of charging low fees, so cost is not the primary barrier to attendance at that service (Maharey, 2007c). Many playcentres have traditionally had a similar fee structure to many Free Kindergartens (Wellington Kindergarten Association, 2006). Within Kindergarten, the high cost of employing teachers is off-set by the large number of children enrolled per teacher, making low fees a possibility, yet Kindergarten is included in the Free ECE policy. It is, therefore, quite ironic that Playcentre is excluded from a policy whose aim is to lower costs to parents, simply because it already has a policy of lowering costs to parents.

That cost is identified as the only barrier to participation is quite revealing of how the economic discourse has come to dominate policy thinking. In line with neoliberal views, the government ignores social and cultural aspects of behaviour in favour of an economic perspective. Groups which make choices on the basis of other criteria are constructed as irrational and a drain on society. Government is privileging economic participation in the community over other forms of community participation, even where those other forms of participation are ostensibly valued by the government. While increased employment is a worthwhile goal, which is indeed chosen by many parents, government talk about the policy seeks to produce a particular parental behaviour by marginalising other choices.

A further concern about the design of the policy is that it fails to address issues around unevenness of supply of ECE places. The policy was initially limited to community-based services, reflecting the Third Way suspicion of market supply of education. But the Third Way is a pragmatic approach to government (Giddens, 1998) and, when confronted by the Opposition and the Early Childhood Council (a network of largely for-profit centre owners), the government changed the policy to include private providers. This dramatically increased the number of child-places potentially available. However, by restricting the Free ECE policy to teacher-led services, the government failed to take 
into account problems of supply, especially in rural areas. Playcentre runs over 470 licensed centres, 40 percent of which are in rural areas (Education Review Office, 2000, p. 38). Kohanga Reo is another important provider of ECE in rural areas. By excluding these parent-led services from the policy, many rural families are unlikely to ever get a place in a service for their child to receive their entitlement. EC centres with high salary costs require a minimum population base to ensure they will be economically sustainable, which may not be achievable in small rural areas. It is also reasonable to expect that some children currently enrolled in parent-led services in urban areas will also enrol in teacher-led services to gain their entitlement, further reducing availability of new child-places. While the government did expand the Discretionary Grants Scheme to enable community-based groups to increase provision, this is still limited to areas of high population. The government failed to develop a plan for universal access, instead relying on the market, which tends largely to go where a profit can be made.

Further, the implication that children are better off in the care of trained teachers implies that parents are incapable of guiding their children's early learning and development, and it is possible that this could become a self-fulfilling prophecy. Parents learn parenting skills through role models, information and training, as well as by spending time with their children (van Wijket al., 2007, p. 59). However, if parents believe the rhetoric that their child is better off in a teacher-led centre they may enrol them for more hours, spend less time in community contexts with their child, and thus have less opportunity to observe and practice positive parenting skills. At base this implies a lack of trust of parents to provide an appropriate environment for their child. It also undermines another government policy initiative, "Team Up", which aims to get parents more involved with their children's education (see $<$ www.teamup.co.nz/default.htm $>$ ).

\section{Conclusion}

The Free ECE policy, providing 20 hours per week free education to all three- and four-year olds in teacher-led services, is a dramatic increase in government participation in early education. It arises from the Third Way conviction that all children should have equivalent access to good quality education as a stepping stone to later full workforce participation, regardless of their parents' employment or income. It demonstrates widespread recognition of the importance of ECE, which is to be applauded. Research over the last decades shows that early education, of a certain standard, makes a significant contribution to children's later education, and life chances. Further, investment in ECE contributes to women'sincreased workforce participation by providing safe care for their young children, thereby contributing to labour market productivity.

However, serious questions remain to be answered about the impacts of the policy in practice. It is unclear whether it will actually have the desired effect of increasing participation, especially of children not currently accessing ECE in any form. Further, the unintended consequences of the policy remain to be explored. For example, services excluded from the policy, either because they are parent-led, or because they choose not to participate in it, are likely to experience change within this new policy climate, yet are not included in the major evaluation planned by the Ministry of Education (Ministry of Education, 2007). What the effects of this policy will be on the overall provision of ECE options in the medium to long term is also unclear. While these are important questions they are outside the scope of this article.

As already noted, the Minister of Education is adamant that this is an education, not workforce, policy (Maharey, 2007c). However, as this article has shown, the policy is designed in such a way that education is equated with time in institutions, with trained teachers and away from parents, and that more hours are, by definition, better. This is despite drawing on independent research, the Competent Children, Competent Learners study (Wylie et al., 1996), which shows that parent-led services, unique to New Zealand, provide an early education at least as good as teacher-led services, and that these good outcomes are achieved in sessional services, such as Kindergarten and Playcentre, which provide fewer than the current average of 14-17 hours per week. The economic rationalist element to Third Way thinking may overshadow social and community development.

That the government has chosen to privilege these particular discourses of education, rather than the education provided by parents either at home or in centres, suggests that the policy is indeed part of a wider policy aim around increasing workforce participation for all adults. However, the long-term effects on children and families of increased institutionalisation is unclear, and this social experiment is being conducted with little public consultation. The questions which the government is avoiding, but which should urgently be addressed, are "what is best for children?", and "how can the government create an environment that supports the development of successful, nurturing families?" 


\section{References}

Ball, S. J., \& Vincent, C. (2005). The "childcare champion"? New Labour, social justice and the childcare market. British Educational Research Journal, 31(5), 557-570.

Canella, G. (1997). Deconstructing early childhood education: Social justice $\mathcal{E}$ revolution. New York: Peter Lang Publishing Inc.

Clark, H. (2005). Statement to Parliament 1 February. Accessed on April 4, 2007, from

$<$ http://labour.org.nz/Our_mps_top/helen_clark/speeches_and_releases/ Speech-HC-050201/index.html >

Dahlberg, G., Moss, P., \& Pence, A. (2007). Beyond quality in early childhood education and care: Languages of Evaluation (2nd ed.). Abingdon: Routledge.

Dalli, C. (2006). Redefining professionalism in early childhood practice: A ground-up approach. Early Childhood Folio 10, 6-11.

Dalli, C., \& Te One, S. (2003). Early childhood education in 2002: Pathways to the future. New Zealand Annual Review of Education, 12, 177-202.

Dixon, R., Widdowson, D., Meagher-Lundberg, P., Airini, \& McMurchyPilkington, C. (2007). Evaluation of promoting early childhood education (ECE) participation project. Report to the Ministry of Education. Wellington: Ministry of Education.

Early Childhood Education Project. (1996). Future directions: Early childhood education in New Zealand. Wellington: NZEI Te Riu Roa.

Education Review Office. (2000). What counts as quality in early childhood centres (Number 4, Winter). Wellington: ERO.

Farquhar, S. (1999). The trouble with "quality". The First Years: New Zealand Journal of Infant and Toddler Education, 1(1), 10-14.

Farquhar, S. (2007). Education expert predicts kindergarten clashes. Press release: Childforum research network. Accessed on July 7, 2007, from <www.scoop.co.nz/stories/ED0706/S00112.htm >.

Farquhar, S., \& Croad, G. (2005). The Competent Children Research: A flagship for public policy and spending in early childhood education and care? Porirua: Childforum Research Network.

Giddens, A. (1998). The third way: The renewal of social democracy. Cambridge: Polity Press.
Maharey, S. (2007a, July 7). Speech at New Zealand Childcare Association Conference. Circulated via email to sector organisations.

Maharey, S. (2007b, April 2). Early Childhood Council Conference speech notes. Accessed on April 13, 2007, from

$<$ www.labour.org.nz/labour_team/mps/mps/steve_maharey/ speeches_and_releases/070331/index.html $>$.

Maharey, S. (2007c, July 2). Frequently asked questions about 20 hours free ECE. Circulated to sector organisations.

May, H. (2001). Politics in the playground: The world of early childhood in postwar New Zealand. Wellington: Bridget Williams Books Limited.

Ministry of Education. (1996). Te Whāriki: He whāriki mātauranga mōng $\bar{a}$ mokopuna o Aotearoa: Early childhood curriculum. Wellington: Learning Media.

Ministry of Education. (2002). Pathways to the Future: Nga Huarahi Arataki: A 10-year strategic plan for early childhood education. Wellington: Ministry of Education.

Ministry of Education. (2007, July 20). Request for proposals with respect to the early effects of free early childhood education (ECE). GETS Tender Watch Notification.

Ministry of Education. (n.d.). Start them up: 20 hours free early childhood education for 3 and 4 year olds. (Pamphlet released in 2006).

Mitchell, L. (2005). Policy shifts in early childhood education: Past lessons, new directions. In J. Codd \& K. Sullivan (Eds.), Education Policy Directions in Aotearoa New Zealand (pp. 175-198). South Bank, Victoria: Thomson/Dunmore Press.

Mitchell, L., Wylie, C., \& Carr, M. (2008). Outcomes of early childhood education literature review. Report to the Ministry of Education. Wellington: Ministry of Education.

Parker, I. (1990). Discourse: Definitions and contradictions. Philosophical Psychology, 2, 190-204.

Podmore, V. N., \& Meade, A. (2000). Aspects of quality in early childhood education. Wellington: New Zealand Council for Educational Research.

Robertson, J. (with Gunn, T. R., Lanumata, T., \& Pryor, J.). (2007). Parental decision making in relation to the use of early childhood education services. Report to the Ministry of Education. Wellington: Roy McKenzie Centre for the Study of Families. 
Shepherd, W., \& Eaton, J. (1997). Creating environments that intrigue and delight children and adults. Child Care Information Exchange, 1(1), 17-18.

Smith, A. (1996). Quality programs that care and educate. Childhood Education: Infancy through to adolescence, 72(6), 330-336.

Smith, A. B., Grima, G., Gaffney, M., Powell, K., Masse, L., \& Barnett, S. (2000). Strategic research initiative literature review: Early childhood education. Report to the Ministry of Education. Dunedin: University of Otago, Children's Issues Centre.

Thrupp, M. (2001). School-level education policy under New Labour and New Zealand Labour: A comparative update. British Journal of Educational Studies, 49(2), 187-212.

van Wijk, N., Simmonds, A., Cubey, P., \& Mitchell, L. (2006). Transforming learning at Wilton Playcentre. Wellington: New Zealand Council for Educational Research.

van Wijk, N. (2007). Wilton Playcentre: A community of learners, tall and short. In A. Meade (Ed.), Cresting the waves: Innovation in early childhood education (pp. 56-62). Wellington: NZCER Press.

Weedon, C. (1997). Feminist practice $\mathcal{E}$ poststructuralist theory (2nd ed.). Oxford: Blackwell Publishers Ltd.

Wellington Kindergarten Association. (2006). Parent newsletter. Unpublished.

Wellington Playcentre Association (Inc.). (1992). Constitution and rules. Wellington: Playcentre Association.

Whyman, P. B. (2006). Third way economics: Theory and evaluation. New York: Palgrave MacMillan.

Wylie, C., Thompson, J., \& Kerslake Hendricks, A. (1996). Competent Children at 5 - Families and early childhood education. Wellington: New Zealand Council for Educational Research.

\section{The author}

Maureen Woodhams is a postgraduate student at Victoria University of Wellington, currently completing a masters degree in education. She has had fourteen years experience as an educator, administrator and parent tutor in Playcentre and is a past president of Wellington Playcentre Association. 